\title{
Antimicrobial Activity of Some Medicinal Plant Extracts against Multidrug Resistant Bacteria
}

\author{
Majid Masoumian, ${ }^{1, *}$ and Mohammad Zandi ${ }^{1}$ \\ ${ }^{1}$ Department of Agriculture, Iranian Research Organization for Science and Technology (IROST), Tehran, IR Iran \\ "Corresponding author: Majid Masoumian, Department of Agriculture, Iranian Research Organization for Science and Technology (IROST), P. O. Box 33535111, Tehran, Iran. Tel: \\ +98-9128177930, E-mail: masoumian200@yahoo.com
}

Received 2016 December 18; Revised 2017 July 18; Accepted 2017 October 07.

\begin{abstract}
Background: Nowadays, it is necessary to discover new and efficient antifungal or antimicrobial drugs because of increasing drug resistance organisms. Using medicinal plants for natural treatment of diseases caused by bacterial origin has mainly been considered.

Objectives: In this study, the impacts of antimicrobial medicinal plants extract were compared based on four bacteria in vitro.

Methods: In this experimental study, disc diffusion assay and the minimum inhibitory concentration (MIC) method were used to investigate the antibacterial effects of selected plant extract elicited by two different solvent on S. aureus, E. coli, P. aeruginosa and S. enteric. Data were analyzed with a statistical software program (SPSS 16).

Results: The hydro-alcoholic extract of Myrtus communis (myrtle) and water extract of Cinnamomun zeylanicum (cinnamon) were the most active extracts screened for antimicrobial activities against different four bacteria as tested organisms. The diameter of inhibition zones ranged from 23 to $28 \mathrm{~mm}$. Comparison of the antibacterial effect of plant extracts and commercial drug revealed that the size of inhibition zone of penicillin against Staphylococcus aureus bacterium was larger than the plant extracts. However, myrtle extract at the minimum inhibitory concentration (MIC) of $30 \mathrm{mg} / \mathrm{mL}$ showed more powerful antibacterial activity compared to the other extracts and even penicillin. Petroselinum crispum (parsley), Nerium oleander (Oleander) and Glycyrihiza glabra (licorice) were found to have the least effect on the tested bacteria.

Conclusions: In the present study, plant extracts with different compounds showed antibacterial activity (especially myrtle and cinnamon). Hence, they can be used as new source for antibacterial substances.
\end{abstract}

Keywords: Medicinal Plants, Antimicrobial Activity, Disc Diffusion Assay, Minimum Inhibitory Concentration

\section{Background}

Excessive usage of antibiotic is destructive to human health, ecosystem, and environment. It could also increase the incidences of drug-resistant pathogens [1]. Antibiotics resistance is a worldwide major problem which is rapidly increasing in both hospitals and the community involved in morbidity, mortality, and health-care [2].

Almost in all pathogenic bacteria, it has been observed that they are able to obtain the resistance factor to the antimicrobial drugs quickly, therefore, multiple drug resistant bacteria caused the main failure in the treatment of infectious diseases $[2,3]$. So, it is necessary to search and design the alternative approaches to control resistant bacteria. One of the possible strategies is rational localization of bioactive phytochemicals with antibacterial activity $[1,4]$. Currently, researchers have investigated plants with extensive variety of secondary compounds that could be a potential source for various antimicrobial agents [5, 6]. Those plants contain numerous structurally unique bioactive compounds which are decent sources to obtain natural therapeutic agents [7]. Coriander, parsley, oleander, myrtle, mint, henna, Aloe vera, christ's thorn, olive, chamomile, cinnamon, licorice, and ginger are some of examples of promising species of medical plants [8].

Coriander (Coriandrum sativum): coriander is rich in vitamins, decanal, nonanal, linalool and many useful substances. It is active against almost all Gram positive and negative bacteria [1, 9]. Parsley (Petroselinum crispum): The herb and root are regularly suggested in traditional medicine for their alleged valuable impacts on gastric, menstrual, and urinary disorders, cough, and myalgia [10]. Oleander (Nerium oleander) is a large glabrous evergreen shrub with milky juice. The inhibitory effect of oleander leaf on certain Gram positive and Gram negative bacteria has been recognized as well [11].

Myrtle (Myrtus communis): Myrtus species are reported as very rich in volatile oils phenolic acids as gallic and ellagic acids, flavonoids, fatty acids (FA), tannins and anthocyanin pigments [12]. Mint (Mentha piperita): Menthol is popular for its disinfectant feature with effective antimicrobial properties that its impact was proved against 21 
pathogen microorganisms [13]. Henna (Lawsonia inermis): is broadly used for medical and cosmetic purposes over the centuries. Henna's bark, leaves, and seeds are used in medicine due to the high amount of phenolic compounds such as flavanol, Lawsone, tannin, gallic acid, glucose, mannitol, fat, resin, mucilage, and phenolic acid [14]. Aloe Vera: its leaves are source of great biologically active compounds, such as anthrones, anthraquinones, and various lectins. Aloe vera has been showed potential antifungal, antiviral and antibacterial activity against skin infections, such as acne, herpes and scabies [15]. Christ's thorn (Ziziphus spina christi) It has been called as "Sedr" in Iran. Flavonoids, alkaloids, triterpenoids, saponins, lipids, proteins, free sugar, and mucilage are the main important compounds characterized in this plant [16]. Olive (Olea europaea): olives contain high concentrations of phenolic compounds. The main types of phenolic compounds present in olives include phenolic acids, phenolic alcohols, flavonoids, and secoiridoids. Hydroxytyrosol and tyrosol are the most abundant phenolic alcohols in olives [17]. Cinnamon (Cinnamomum zeylanicum): The procyanidine polyphenol from various natural sources are reported to offer strong protection against oxidative stress to primary glial cells [18]. Licorice (Glycyrrhiza glabra): more than 80 different ingredients of liquorice preparations have been known such as flavonoids, chalcones, and coumarone. The core biologically active compound of the liquorice root is glycyrrhizic acid or glycyrrhizin [19].

The present study aimed to evaluate antimicrobial effects of selected plants and combination of them against Staphylococcus aureus, Escherichia coli, Pseudomonas aeruginosa and Salmonella enteric isolates. These bacteria are resistant to the most common antibiotics [20].

\section{Methods}

\subsection{Water Extracts Distillation}

Coriander and parsley provided seeds; oleander, myrtle, mint, henna, aloe vera, christ's thorn and olive provided leaves; chamomile flowers; cinnamon bark; licorice; and ginger roots were collected from Iranian research organization for Science and technology. By early washing, additions and dirties were removed and then plants were washed by distilled water. After that, plants were placed in dryer oven for two days. Dried plants were grinded and prepared for extraction. The aqueous extract was pulled out with Soxhlet apparatus. From each plant, 40 gram of powder was placed in filter paper bags, and water-soluble extract in $400 \mathrm{~mL}$ of distilled water was removed. The dilute extracts were poured in evaporator to remove the excessive water at temperature of $40^{\circ} \mathrm{C}$. Then, samples were centrifuged ( $3000 \mathrm{rpm}, 5$ minutes) to eliminate the impuritiesand suspended solids. The supernatants were used as aqueous crude extract in this study.

\subsection{Hydro-Alcoholic Extraction}

The plants powders were prepared as explained in previous section. For hydro-alcoholic extraction, the powders were placed in flasks individually. Water and alcohol at a ratio of 50:50 in specified deal were added to the flasks and kept 24 hours in dark. Samples were poured in rotary evaporator to remove as much as possible extra water and alcohol. Then, the concentrated samples were centrifuged (3000 rpm, 5 minutes) and supernatants were used as hydro-alcoholic crude extract in this study.

\subsection{Dry Weight Determination of Aqueous and Hydro-Alcoholic Plant Extracts}

The weight of a plate was measured, and then $5 \mathrm{~mL}$ of each plant extracts (aqueous and hydro-alcoholic) were poured into the plates individually. The contents of the plate were dried at oven. On average, three replicates of weight differences were considered as the dry weight of the extract [21].

\subsection{Bacterial Culture}

Staphylococcus aureus (ptcc 1764), Escherichia coli (ptcc 1399), Pseudomonas aeruginosa (ptcc 1310), and Salmonella enteric sub specie (ptcc 1709) were purchased from the Persian type culture collection (PTCC), IROST, Iran. Bacteria were cultured in brain heart infusion (BHI) medium (Sigma-Aldrich) and used for assays [22, 23].

\subsection{Zone of Inhibition Test}

The antibacterial assay was based on the standard agar diffusion assay. One colony of each bacterium was picked off from a stock plate and suspended in deionized water individually. An aliquot of bacterium suspension was swabbed on agar plates (BHI-agar).Then, six holes were perforated in each plate and $100 \mu \mathrm{L}$ of the same concentration of each plant extracts were poured in the hole. The plates were incubated at $37^{\circ} \mathrm{C}$ for 24 hours and then the diameter of the growth inhibition around each hole was measured [24].

\subsection{Minimum Inhibitory Concentration (MIC) Test}

The plant extracts that had a better inhibition zone were selected and used for MIC test. Half McFarland concentrations $\left(\mathrm{OD}_{620 \mathrm{~nm}}=0.1\right)$ of each bacterium was cultured in both BHI medium in a universal bottle and five concentrations of selected plant extracts $(10,20,30,40$ and 50 $\mathrm{mg} / \mathrm{mL})$, and penicillin $(10,20,30,40$ and $50 \mu \mathrm{g} / \mathrm{mL})$ was 
individually added to the bottles. In addition, $30 \mu \mathrm{g} / \mathrm{mL}$ of gentamicin was used for Gram negative bacteria alongside with different concentration of penicillin. The controls were contained only half McFarland concentrations $\left(\mathrm{OD}_{620 \mathrm{~nm}}=0.1\right)$ of each bacterium. The bottles were incubated at $37^{\circ} \mathrm{C}$ for 24 hours. The $\mathrm{OD}_{620 \mathrm{~nm}}$ of the samples was recorded at the end of incubation. MIC was considered as the lowest concentration of the sample preventing visible growth, which $\mathrm{OD}_{620 \mathrm{~nm}}$ less than 0.2 was considered to have no visible bacterial growth. All samples were examined in three separate experiments [1].

\subsection{Synergistic Effect}

To study the synergistic effect, extracts with higher antibacterial effects were selected, including hydro-alcoholic extracts of myrtle and chamomile and water extract distillation of henna, aloe vera, christ's thorn and cinnamon. Four treatments of equally mixed plant extracts were tested on S. aureus and P. aeruginosa [25].

\subsection{Statistical Analysis}

Data were analyzed with a statistical software program (SPSS 16). Comparisons between multiple numeric datasets were performed using one-way ANOVA followed by Duncan multiple-range test. Results are expressed as mean \pm SEM., and statistical significance was accepted at $\mathrm{P}<0.05$.

\section{Results}

\subsection{Antimicrobial Activity of Plant Extracts}

The results showed that the most active organic solvent to extract the antibacterial compounds from tested plants was ethanol. As shown in Table 1, water extract distillation of parsley, oleander, olive, licorice, and ginger could not inhibit the growth of tested bacteria while hydro-alcoholic extracts of them prevented the growth of some and/or all of the tested bacteria (hydro-alcoholic extract of ginger).

The hydro-alcoholic extracts of myrtle, chamomile, and ginger were able to inhibit the growth of all tested bacteria while only aqueous extract of henna showed the inhibitory effect against all bacteria. The highest zones of inhibition were recorded for the hydro-alcoholic extract of myrtle followed by aqueous extract of cinnamon and hydro-alcoholic extract of licorice, which were 28,23 , and $22 \mathrm{~mm}$ in diameters, respectively. In addition, between the four tested bacteria, the growth of S. aureus was more effected by the plant extracts followed by $S$. enteric, P. aeruginosa and E. coli.
The growth of $S$. aureus was inhibited by the aqueous extraction of cinnamon, henna, Aloe vera, coriander, myrtle and chamomile and hydro-alcoholic extraction of myrtle, mint, henna, ginger, chamomile, cinnamon, coriander, olive, and christ's thorn by displaying the zone of inhibition between 10 to $23 \mathrm{~mm}$ and 10 to $28 \mathrm{~mm}$, respectively.

Moreover, among different herbal extracts, aqueous extraction of henna, mint, christ's thorn, and chamomile as well as hydro-alcoholic extraction of myrtle, chamomile, ginger, and parsley had antibacterial effects on E. coli by exhibition the zone of inhibition between 10 to $18 \mathrm{~mm}$ and 10 to $13 \mathrm{~mm}$, respectively.

Moreover, aqueous extraction of Aloe vera, christ's thorn, mint, cinnamon, henna and hydro-alcoholic extraction of myrtle, ginger, and chamomile inhibited the growth of $P$. aeruginosa by presenting the zone of inhibition size between 10 to $20 \mathrm{~mm}$ and 10 to $15 \mathrm{~mm}$, respectively.

Furthermore, aqueous extraction of myrtle, Aloe vera, mint, christ's thorn, cinnamon, henna and hydro-alcoholic extraction of licorice, ginger, myrtle, oleander, olive, and chamomile repressed the growth of $S$. enteric by demonstrating the zone of inhibition between 10 to $20 \mathrm{~mm}$ and 10 to $22 \mathrm{~mm}$, respectively.

Among all four bacteria, only S. enteric exposed more sensitivity to hydro-alcoholic extract of licorice and aqueous extracts of myrtle and Aloevera compared to penicillin (22, 20 and $20 \mathrm{~mm}$ vs. $18 \mathrm{~mm}$, respectively). Also, P. aeruginosa showed similar sensitivity to aqueous extract of Aloe vera compared to penicillin $(20 \mathrm{~mm}$ vs. $20 \mathrm{~mm}$, respectively).

\subsection{Minimum Inhibitory Concentration (MIC)}

The minimum inhibitory concentration (MIC) was studied on eight different plant extracts (including both aqueous and hydro-alcoholic extracts) using different concentration against different bacteria (Figure 1). The $\mathrm{OD}_{620 \mathrm{~nm}}$ of bacterial growth contained the plant extracts compared with growth of bacterial culture, which contained no extracts. Moreover, for each bacterium, different concentration of penicillin was tested as the control. The turbidity of the cultures with the $\mathrm{OD}_{620 \mathrm{~nm}}$ less than 0.2 was not visible. The results showed that all extracts could inhibit the growth of all four tested bacteria but with different sensitivity. The MIC of penicillin against different tested bacteria was $30 \mu \mathrm{g} / \mathrm{mL}$. Among the plants tested, hydro-alcoholic extract of myrtle and aqueous extracts of cinnamon, mint, christ's thorn, and Aloe vera showed strong activity against $S$. aureus (for the first two extracts), E. coli, P. aeruginosa, and S. enteric with the best MIC at $30 \mathrm{mg} / \mathrm{mL}$, respectively. In addition, the MIC values 
Table 1. Comparison of the Effects of Different Plant Extracts (Aqueous and Hydro-Alcoholic Extraction) on Four Bacteria Using Agar Diffusion Assay ${ }^{a, b}$

\begin{tabular}{|c|c|c|c|c|c|}
\hline Plant Part Used & Plant Extract & S. aureus & E. coli & P. aeruginosa & S. enteric \\
\hline \multirow{4}{*}{ Seed } & Aqueous Coriander & 15 & 0 & 0 & 0 \\
\hline & $\begin{array}{l}\text { Hydro-alcoholic } \\
\text { Coriander }\end{array}$ & 15 & 0 & 0 & 0 \\
\hline & Aqueous Parsley & 0 & 0 & 0 & 0 \\
\hline & Hydro-alcoholic Parsley & 0 & 10 & 0 & 0 \\
\hline \multirow{14}{*}{ Leaf } & Aqueous Oleander & 0 & 0 & 0 & 0 \\
\hline & $\begin{array}{l}\text { Hydro-alcoholic } \\
\text { Oleander }\end{array}$ & 0 & 0 & 0 & 12 \\
\hline & Aqueous Myrtle & 15 & 0 & 0 & 20 \\
\hline & Hydro-alcoholic Myrtle & 28 & 13 & 15 & 14 \\
\hline & Aqueous Mint & 0 & 17 & 15 & 17 \\
\hline & Hydro-alcoholic Mint & 19 & 0 & 0 & 0 \\
\hline & Aqueous Henna & 20 & 18 & 10 & 10 \\
\hline & Hydro-alcoholic Henna & 18 & 0 & 0 & 0 \\
\hline & Aqueous Aloe vera & 17 & 0 & 20 & 20 \\
\hline & $\begin{array}{l}\text { Hydro-alcoholic Aloe } \\
\text { vera }\end{array}$ & 0 & 0 & 0 & 0 \\
\hline & Aqueous Christ's thorn & 0 & 15 & 16 & 14 \\
\hline & $\begin{array}{l}\text { Hydro-alcoholic Christ's } \\
\text { thorn }\end{array}$ & 10 & 0 & 0 & 0 \\
\hline & Aqueous Olive & 0 & 0 & 0 & 0 \\
\hline & Hydro-alcoholic Olive & 13 & 0 & 0 & 10 \\
\hline \multirow{2}{*}{ Flower } & Aqueous Chamomile & 10 & 10 & 0 & 0 \\
\hline & $\begin{array}{c}\text { Hydro-alcoholic } \\
\text { Chamomile }\end{array}$ & 17 & 13 & 10 & 10 \\
\hline \multirow{2}{*}{ Bark } & Aqueous Cinnamon & 23 & 0 & 14 & 14 \\
\hline & $\begin{array}{c}\text { Hydro-alcoholic } \\
\text { Cinnamon }\end{array}$ & 16 & 0 & 0 & 0 \\
\hline \multirow{4}{*}{ Root } & Aqueous Licorice & 0 & 0 & 0 & 0 \\
\hline & $\begin{array}{c}\text { Hydro-alcoholic } \\
\text { Licorice }\end{array}$ & 0 & 0 & 0 & 22 \\
\hline & Aqueous Ginger & 0 & 0 & 0 & 0 \\
\hline & Hydro-alcoholic Ginger & 18 & 13 & 15 & 15 \\
\hline Control & Penicillin* & 32 & 20 & 20 & 18 \\
\hline
\end{tabular}

${ }^{\mathrm{a}}$ The data are in millimeter and recorded after 24 hours incubation of agar plates at $37^{\circ} \mathrm{C}$. The data are expressed as the mean.

${ }^{\mathrm{b}}$ A combination of penicillin with $30 \mu \mathrm{g} / \mathrm{mL}$ of gentamicin was used against $E$. coli and P. aeruginosa.

of hydro-alcoholic extract of mint and aqueous extract of henna and myrtle to inhibit.

The growth of S. aureus, E. coli and S. enteric were 40 $\mathrm{mg} / \mathrm{mL}$, respectively. The MIC of aqueous Aloe vera and mint against $P$. aeruginosa and $S$. enteric were $50 \mathrm{mg} / \mathrm{L}$ respectively. While, $30 \mathrm{mg} / \mathrm{mL}$ of aqueous extract of cinnamon inhibited the growth of Gram-positive S. aureus; the MIC of this extract against Gram negative P. aeruginosa was higher than $50 \mathrm{mg} / \mathrm{mL}$.

\subsection{Synergistic Effect}

To study the synergistic effect, few extracts were chosen based on the results of the first experiment, involving hydro-alcoholic extracts of myrtle and chamomile and aqueous extracts of henna, Aloe vera, Christ|s thorn and cinnamon. Four different combinations of effective herbal 




Different Plant Extracts/Different Tested Bacteria

Concentration used for plant extract was $\mathrm{mg} / \mathrm{mL}$ and for penicillin was $\mu \mathrm{g} / \mathrm{mL}$. Samples were incubated at $37^{\circ} \mathrm{C}$ for 24 hours. Culture bacteria containing no plant extract or antibiotics were considered as control. The data are expressed as the mean. Note: A combination of different concentration of penicillin with $30 \mu \mathrm{g} / \mathrm{mL}$ of gentamicin was used against $E$. coli and $P$. aeruginosa.

extracts were tested to overcome the resistance of Grampositive (S. aureus) and Gram-negative (P.aeruginosa) bacteria (Table 2). Results showed that combination of myrtle, henna, and Aloe vera were more effective than the other treatments by displaying the inhibition zone of 15 and $21 \mathrm{~mm}$ against the growth of $P$. aeruginosa and $S$. aureus, respectively. However, the result of the first experiment showed myrtle, henna and Aloe vera individually caused 28,20 , and $17 \mathrm{~mm}$ diameter of inhibition zone on $S$. aureus culture. Therefore, it can be concluded that theses extracts contained compounds which presented antagonist effect on growth inhibition of tested bacteria. The same effect was observed to study the combination of extracts on $P$. aeruginosa even lower diameter of inhibition zone on $P$. aeruginosa culture was detected.

\section{Discussion}

Increasing the number of multi-drug resistance pathogenic microbes in human and animal as well as unwanted side effects of certain antibiotics has encouraged enormous interest to search for new antimicrobial drugs of plant origin [26].

All of the four tested bacteria in this study approximately responded to water extract distillation and hydroalcoholic extracts with greater result for hydro-alcoholic extract. However, it has been reported by many researchers that hydro-alcoholic extract, compared to the aqueous extract, is more effective and has a superior inhibitory influence [27].

The present investigation showed that water extract distillation and hydro-alcoholic extract of coriander had no effect on Gram-negative bacteria. However, Kubo et al. [28] showed positive effect of coriander on Salmonella, which is a Gram-negative bacterium. Antibacterial activity of coriander is due to the presence of alpha, betaunsaturated aldehydes [29]. In a survey, Toroglu [30] reported the inhibitory effect of coriander on different Gram-positive and Gram-negative bacteria. In addition, Lo Cantore et al. [31] considered antimicrobial properties for coriander in their study. Another study reported that volatile compounds of coriander could possess bactericidal activity against Salmonellacholera [32]. 
Table 2. Comparison of the Effects of Combining Selected Herbal Extract on the Two Bacteria Using Agar Diffusion Assay

\begin{tabular}{lcc}
\hline Treatment Combination & S.aureus & \\
\hline Myrtle, Henna, Aloe vera & 21 \\
Myrtle, Henna, Aloe vera, Chamomile, Christ's thorn & 15 & 15 \\
\hline Myrtle, Henna, Aloe vera, Chamomile, Christ's thorn, Cinnamon & 15 & 19 \\
Chamomile, Christ's thorn, Cinnamon & 14 & 18 \\
\hline
\end{tabular}

${ }^{\mathrm{a}}$ The data are in millimeter and recorded after 24 hours incubation of agar plates at $37^{\circ} \mathrm{C}$. The data are expressed as the mean.

Dorman et al. [10] pointed out that parsley, in addition to antimicrobial effect, has remarkable antioxidant effect because it contains carotenoids, coumarins, flavonoids, tannins and triterpenes. Manderfeld et al. [33] suggested that anti-microbial effects of parsley is related to the presence of furocoumarins compound in this plant. However, in the present research, both water extract distillation and hydro-alcoholic extract of parsley did not show appropriate antibacterial properties.

In this study, S. aureus showed more sensitivity to most of aqueous and hydro-alcoholic plant extracts, but the different effect was observed in aqueous extracts of mint and christ's thorn, which only inhibited the growth of all Gramnegative tested bacteria. Only $10 \mathrm{mg} / \mathrm{mL}$ of the aqueous extracts of mint and christ's thorn inhibited the growth of $E$. coli and P. aeruginosa to less than $35 \%$ of the control. However, the hydro-alcoholic extracts of these two plants could only inhibit the growth of S. aureus and not the Gramnegative bacteria. According to Abouhosseini Tabari et al. [13], mint essence had a weak effect on both Gram-negative and positive bacteria (E. coli and S. aureus, respectively). One of the mint components is hydrophobic, which could disintegrate the bacterial cell wall and cause disruption in their structure and permeation. Sabahat et al. [34] investigated the effect of juice and essential oil of mint on several bacteria and observed antibacterial activity with 11.78 $\mathrm{mm}$ mean inhibition zone. In addition, in another study regarding the antimicrobial effects of mint essence, Aridogan et al. [35] confirmed the presence of antimicrobial agent against $S$. aureus and E. coli. Also, Iscan et al. [36] reported the significant inhibitory impact of mint extract against two Gram-positive (Bacillus subtilis and S. aureus) and two Gram-negative (E. coli and P. aeruginosa) bacteria. However, Shan et al., [37] reported that in vitro antibacterial activity test of mint extract showed wider diameter of inhibition zone on $S$. aureus culture compared to the $E$. coli, which was observed in the present study. Derwich et al. [21] reported that mostly aqueous plant extract was effective on Gram-negative and hydro-alcoholic extract was effective on Gram-positive bacteria such as christ's thorn, which is a herb with thirty essential oils.
Myrtle and henna are two herbs with many bioactive compounds. Polyphenols are common compounds in myrtle and henna that have antioxidant and antibacterial effects [26]. Nevertheless, in the current study, the most antibacterial effect of myrtle was for hydro-alcoholic extract, while henna was affected by water extract distillation. In addition, $20 \mathrm{mg} / \mathrm{mL}$ of aqueous extracts of myrtle and henna prevented more than $50 \%$ of $S$. enteric and E. coli growth, respectively, while only $10 \mathrm{mg} / \mathrm{mL}$ of hydroalcoholic extract of myrtle was able to reduce the growth of S. aureusto less than $25 \%$ compared to the control. By taking into account 20 of ethanol extracts plants species, which are Yemeni traditional herbals to treat infectious diseases, Ali et al. [38] found that ethyl acetate extract of henna was the most active antibacterial against all the bacteria in the test system. Moreover, Baba-Moussa et al. [39] indicated that water extract distillation of leaves of henna had the substantial antibacterial effect. Quinonic compounds from henna were studied in-vitro for antimicrobial properties. Genotoxic studies on lawsone (or hennotannic acid), which is a dye present in the leaves of the henna plant, showed a weak bacterial mutagen for Salmonella typhimurium strain TA98 and more clearly mutagenic for straining TA2637. However, Kirkland and Marzin [40] stated that the weight of evidence revealed henna possess no genotoxic risk to the consumer.

Similarly, Thakur et al. [41] reported that ethanolic extract of cinnamon was not effective on Gram-negative bacteria, but ginger prevented the growth of the bacteria. Cinnamon has many bioactive compounds including alkaloids, flavones, phenols, quinones, terpenoids, glycosides, and tannins known to possess antibacterial activity [41]. Selecting appropriate solvent to extract the antibacterial compound from plant is crucial because inhibition zone of water extract distillation of cinnamon in the present study was remarkable especially on S. aureus, which is similar to the study done by Buru et al. [42]. Only $10 \mathrm{mg} / \mathrm{mL}$ of the aqueous extract of cinnamon inhibited more than $40 \%$ of the growth of $S$. aureus.

The same result with Nitalikar et al. [19] study showed that licorice extracts (both water distillation and hydro- 
alcoholic extracts) had no antibacterial activity except for its hydro-alcoholic extract, which could inhibit the growth of S. enteric by displaying a wide inhibition zone. Jastaniah [1] studied the proper antibacterial effect of phenolic compound of oleander and olive leaves, however, in the present research, only the hydro-alcoholic extracts of these two leaves could inhibit the growth of S. aureus and S. enteric.

Antibacterial activity of oleander on certain Grampositive and Gram-negative bacteria was studied and considerable antimicrobial activity was found [11].The antimicrobial activity may be due to a wide variety of secondary metabolites, such as tannins, terpenoids, alkaloids, and flavonoids, which have antimicrobial activities [7].

Also, Aloe vera leaf was recognized as increasing collagen building, but its antibacterial effect was not negligible. Mannans, polymannans, anthraquinone c-glycosides, anthrones, anthraquinones, and various lectins are recognized as bioactive compound of Aloe vera [15]. In the present study, aqueous aloe vera extract demonstrated a good antibacterial activity against $P$. aeruginosa, $S$. enteric and $S$. aureus, and only $20 \mathrm{mg} / \mathrm{mL}$ of the Aloe vera extract inhibited more than $50 \%$ of $P$. aeruginosa and S. enteric growth.

Overall, all the plant extracts even at $10 \mathrm{mg} / \mathrm{mL}$ concentration inhibited the growth of tested bacteria compared to the control containing no extract. It can be found that the antimicrobial agents are presented in the extracts. However, the synergistic effect study showed that the mixture of these extracts could reduce their inhibitory effects. Abouhosseini Tabari et al. [13] found that synergistic effect was not observed in combination 1:1 of mint and eucalyptus (myrtle family) essence. Even this combination managed to reduce the antimicrobial activity and the inhibition was less than mint and eucalyptus essence individually. This result might be due to some components in mint and eucalyptus essences, which are antagonists and might neutralize each other and weaken their antimicrobial activity.

To sum up, Gram-negative bacteria show more resistance to the available antibiotics [43]. Comparative study on the cell wall structures of bacteria reveals that Grampositive bacteria have thick peptidoglycan in their cell wall composition while Gram-negative bacteria have only a thin layer of peptidoglycan, but rich in lipoprotein and lipopolysaccharides in their cell structure. Thus, Gram negative bacteria are more resistant [43]. Hence, the effects of antimicrobial agent against Gram positives bacteria were more tangible than those against the Gram negatives. It seems obviously that the active compounds belong to the lipophilic group rather than to the hydrophilic one [26].

\subsection{Conclusion}

Plant extracts contained a very complex structure with the active ingredients present in the form of natural organic compounds. The process of extraction for a particular compound is dependent on the solubility of the component in the solvent (water or organic solvent). The process and extraction system are constantly different with every product and compound. The crude extracts of the tested plants demonstrated good potential antibacterial activities. The potential to develop antimicrobial compounds from higher plants appears rewarding as it will propel to the expansion of a phytomedicine to turn against multidrug resistant microbes.

\section{Acknowledgments}

We would like to thank Mr. Asgr Shariatinia for their helpful comments during the research. The authors are all grateful to agricultural institute of IROST for providing this study with laboratory facilities and other technical support. This research approved in research committee by code:11-1.

\section{Footnotes}

Authors' Contribution: Majid Masoumian was involved in the experimental design, data collection, data analysis and manuscript editing. Mohammad Zandi was involved in study design, data interpretation and manuscript editing. All authors have read and approved the final manuscript.

Conflict of Interests: The authors declare that they have no conflict of interest.

Funding/Support: Royan Kesht Yakhteh Co.

\section{References}

1. Jastaniah SD. The antimicrobial activity of some plant extracts, commonly used by Saudi people, against multidrug resistant bacteria. Life Sci J. 2014;11(8):78-84.

2. Mill Robertson FC, Onyeka CI, Tay SCK, Walana W. In vitro antimicrobila activity of antibact, and herbal medicinal productt against standard and clonical bacterila isolates. J Med Plants Res. 2015;9(11):370-8. doi: 10.5897/JMPR2015.5758.

3. Bisht R, Katiyar A, Singh R, Mittal P. Antibiotic resistance a global issue of concern. Asian J Pharm Clin Res. 2009;2:34-9.

4. Ushimaru PI, Silva M, Di Stasi LC, Barbosa L, Fernandes Junior A. Antibacterial activity of medicinal plant extracts. Braz J Microbiol. 2007;38(4):717-9. doi: 10.1590/s1517-83822007000400024.

5. Amer S, Aly MM, Sabbagh S. Biocontrol of dermatophytes using some plant extracts and actinomycetes filtrates. Egypt JBiotech. 2007;14:291315.

6. Mahmoud YA, Ebrahium MK, Aly MM. Influence of some plant extracts and microbioagents on some physiological traits of faba bean infected with Botrytis faba. Turkish J Bot. 2004;7:21-30. 
7. Cowan MM. Plant products as antimicrobial agents. Clin Microbiol Rev. 1999;12(4):564-82. [PubMed: 10515903].

8. Zohourian TH, Quitain AT, Sasaki M, Goto M. Polyphenolic contents and antioxidant activities of Lawsonia inermis leaf extracts obtained by microwave-assisted hydrothermal method. J Microw Power Electromagn Energy. 2011;45(4):193-204. [PubMed: 24428109].

9. Cao XZ, You JM, Li SX, Zhang YL. Antimicrobial activity of the extracts from Coriandrum sativum. Int J Food Nutr Saf. 2012;1(2):54-9.

10. Dorman HJ, Lantto TA, Raasmaja A, Hiltunen R. Antioxidant, prooxidant and cytotoxic properties of parsley. Food Funct. 2011;2(6):32837. doi: 10.1039/c1fo10027k. [PubMed: 21779571].

11. Hussain MA, Gorsi MS. Antimicrobial activity of Nerium oleander Linn. Asian J Plant Sci. 2004;3(2):177-80. doi:10.3923/ajps.2004.177.180.

12. Nassar MI, Aboutabl el SA, Ahmed RF, El-Khrisy ED, Ibrahim KM, Sleem AA. Secondary metabolites and bioactivities of Myrtus communis. Pharmacognosy Res. 2010;2(6):325-9. doi: 10.4103/0974-8490.75449. [PubMed: 21713133].

13. Abouhosseini Tabari M, Youssefi MR, Ghasemi F, Ghias Tabari R, Haji Esmaili R, Yousefi Behzadi M. Comparison of antibacterial effects of Eucalyptus essence, Mint essence and combination of them on Staphylococcus aureus and Escherichia coli isolates. Middle East J Sci Res. 2012;11(4):536-40.

14. Uma DB, Ho CW, Wan Anaida WM. Optimization of extraction parameters of total phenolic compounds from Henna, (Lawsonia inermis) leaves. Sains Malays. 2010;39(1):119-28.

15. Irshad $S$, Butt $M$, Younus $H$. In vitro antibacterial activity of Aloe barbadensis Miller, (Aloe vera). Int Res J Pharm. 2011;1(2):59-64.

16. Asgarpanah J. Phytochemistry and pharmacologic properties of Ziziphus spina christi, (L.) Willd. Afr J Pharm Pharmacol. 2010;6(31):2332-9. doi: 10.5897/ajpp12.509.

17. Silva S, Gomes L, Leitao F, Coelho AV, Boas LV. Phenolic compounds and antioxidant activity of Olea europaea L. fruits and leaves. Food Sci Technol Int. 2006;12(5):385-95. doi: 10.1177/1082013206070166.

18. Roychowdhury S, Wolf G, Keilhoff G, Bagchi D, Horn T. Protection of primary glial cells by grape seed proanthocyanidin extract against nitrosative/oxidative stress. Nitric Oxide. 2001;5(2):137-49. doi: 10.1006/niox.2001.0335. [PubMed: 11292363]

19. Nitalikar MM, Munde KC, Dhore BV, Shikalgar SN. Studies of antibacterial activities of Glycyrrhiza glabra root extract. Int J Pharmtech Res. 2010;2(1):899-901.

20. Gorwitz RJ, Kruszon-Moran D, McAllister SK, McQuillan G, McDougal LK, Fosheim GE, et al. Changes in the prevalence of nasal colonization with Staphylococcus aureus in the United States, 2001-2004. I Infect Dis. 2008;197(9):1226-34. doi:10.1086/533494. [PubMed: 18422434].

21. Derwich E, Benziane Z, Boukir A. Chemical composition and In vitro antibacterial activity of the essential oil of Cedrus atlantica. Int J Agric Biol. 2010;12:381-5.

22. Brown DF, Edwards DI, Hawkey PM, Morrison D, Ridgway GL, Towner $\mathrm{KJ}$, et al. Guidelines for the laboratory diagnosis and susceptibility testing of methicillin-resistant Staphylococcus aureus (MRSA). J Antimicrob Chemother. 2005;56(6):1000-18. doi: 10.1093/jac/dki372. [PubMed: 16293678].

23. Mueller $\mathrm{JH}$, Hinton J. A protein free medium for primary isolation of the gonococcus and meningococcus. Exp Biol Med. 1941;48(1):330-3. doi: 10.3181/00379727-48-13311.

24. Aly MM, Gumgumjee NM. Antimicrobial efficacy of Rheum palmatum, Curcuma longa and Alpinia officinarum extracts against some pathogenic microorganisms. Afr J Biotechnol. 2011;10(56):12058-63. doi: 10.5897/ajb11.1431.

25. Nguefack J, Tamgue O, Dongmo JBL, Dakole CD, Leth V, Vismer HF, et al. Synergistic action between fractions of essential oils from Cymbopogon citratus, Ocimum gratissimum and Thymus vulgaris against Penicillium expansum. Food Control. 2012;23(2):377-83. doi: 10.1016/j.foodcont.2011.08.002.
26. Rahmoun MN, Benabdallah M, Villemin D, Boucherit K, Mostefa Kara $\mathrm{B}, \mathrm{Ziani}$ Cherif C. Antimicrobial screening of the Algerian lawsonia inermis, (henna). Der Pharma Chemica. 2010;2(6):320-6.

27. Alizadeh Behbahani B, Tabatabaei Yazdi F, Shahidi F, Mohebbi M. Antimicrobial activity of Avicennia marina extracts ethanol, methanol and glycerin against Penicillium digitatum, (citrus green mold). Sci J Microbiol. 2012;1(7):147-51.

28. Kubo I, Fujita K, Kubo A, Nihei K, Ogura T. Antibacterial activity of coriander volatile compounds against Salmonella choleraesuis. $J$ Agric Food Chem. 2004;52(11):3329-32. doi:10.1021/jf0354186. [PubMed: 15161192].

29. Moradian H, Bazargani A, Rafiee A, Nazarialam A. In vitro comparison of antimicrobial activity of aqueous decoction of Coriandrum sativum, and Dentol Drop with chlorhexidine on Streptococcus mutans. Iran J Microbiol. 2013;5(3):239-43. [PubMed: 24475330].

30. Toroglu S. In-vitro antimicrobial activity and synergistic/antagonistic effect of interactions between antibiotics and some spice essential oils. J Environ Biol. 2011;32(1):23-9. [PubMed: 21888227].

31. Lo Cantore P, Iacobellis NS, De Marco A, Capasso F, Senatore F. Antibacterial activity of Coriandrum sativum L. and Foeniculum vulgare Miller Var. vulgare (Miller) essential oils. I Agric Food Chem. 2004;52(26):7862-6. doi:10.1021/jf0493122. [PubMed:15612768].

32. Chaudhry NM, Tariq P. Bactericidal activity of black pepper, bay leaf, aniseed and coriander against oral isolates. Pak J Pharm Sci. 2006;19(3):214-8. [PubMed: 16935829].

33. Manderfeld MM, Schafer HW, Davidson PM, Zottola EA. Isolation and identification of antimicrobial furocoumarins from parsley. J Food Prot. 1997;60(1):72-7. [PubMed:10465045].

34. Sabahat $S$, Naim A, Tariq P. In vitro antibactrial activity of peppermint PakJ Bot. 2006;38(3):869-72.

35. Aridogan BC, Baydar H, Kaya S, Demirci M, Ozbasar D, Mumcu E. Antimicrobial activity and chemical composition of some essential oils. Arch Pharm Res. 2002;25(6):860-4. [PubMed: 12510839].

36. Iscan G, Kirimer N, Kurkcuoglu M, Baser KH, Demirci F. Antimicrobial screening of Mentha piperita essential oils. J Agric Food Chem. 2002;50(14):3943-6. [PubMed: 12083863].

37. Shan B, Cai YZ, Brooks JD, Corke H. The in vitro antibacterial activity of dietary spice and medicinal herb extracts. Int J Food Microbiol. 2007;117(1):112-9. doi: 10.1016/j.ijfoodmicro.2007.03.003. [PubMed 17449125].

38. Ali NA, Julich WD, Kusnick C, Lindequist U. Screening of Yemeni medicinal plants for antibacterial and cytotoxic activities. $J$ Ethnopharmacol. 2001;74(2):173-9. [PubMed: 11167035].

39. Baba Moussa F, Nacoulma O, Ouattara A, Nguyen HP, Akpagana K Bouchet P. Antibacterial activity of total aqueous extracts of Combretum micranthum, Lawsonia inermis and Waltheria indica, plants from west African pharmacopoeia. Rev Med Pharm Afr. 1997;11(12):197203.

40. Kirkland D, Marzin D. An assessment of the genotoxicity of 2-hydroxy1,4-naphthoquinone, the natural dye ingredient of Henna. Mutat Res. 2003;537(2):183-99. [PubMed: 12787822].

41. Thakur R. Study of antioxidant, antibacterial and anti-inflammatory activity of cinnamon, (Cinamomum tamala), ginger, (Zingiber officinale) and turmeric, (Curcuma longa). Am J Life Sci. 2013;1(6):273. doi: 10.11648/j.ajls.20130106.16.

42. Buru AS, Pichika MR, Neela V, Mohandas K. In vitro antibacterial effects of Cinnamomum extracts on common bacteria found in wound infections with emphasis on methicillin-resistant Staphylococcus aureus. J Ethnopharmacol. 2014;153(3):587-95. doi: 10.1016/j.jep.2014.02.044. [PubMed: 24613273].

43. Ghalem BR, Mohamed B. Antibacterial activity of leaf essential oils of Eucalyptus globulus and Eucalyptus camaldulensis. Afr J Pharm Phar macol. 2008;2(10):211-5. 